\section{Tom Fouch Joins the Foundation's Board of Trustees}

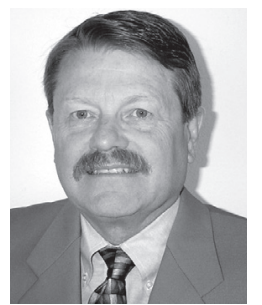

Thomas D. Fouch

I am pleased to announce that Thomas D. Fouch has joined GSA Foundation's Board of Trustees. He will serve a five year term, which began at the November 2004 meeting of the Board. Fouch also served as president of the Foundation from January 2002-2004, where he was successful in raising funds for several GSA projects

Fouch worked for the U.S. Geological Survey for 27 years until his retirement in December 2001. Previously, he spent one year with J.M. Huber and five years with Shell Oil. He received his B.S. degree in earth science in 1966 from Portland State University in Oregon and his M.S. degree in geology in 1968 from the University of Oregon.

Fouch has extensive experience as a leader, a manager, a strategic planner, and an implementer, and he brings to GSA Foundation's Board a broad background in program development, program evaluation, and resource planning. He is also skilled at representing his organization to outside groups or agencies. He has a reputation as a trusted, credible, and respected team player with a warm personality and remarkable people skills. His work ethic, long history of performance, and intellectual capacity are all exceptional and will be helpful in the Foundation's quest to be successful in its efforts to seek funds in support of GSA programs and activities.

Welcome aboard Tom!

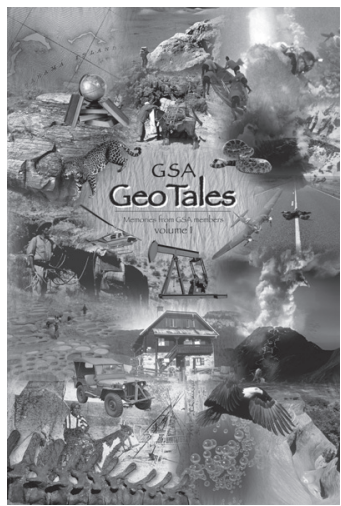

\section{GeoTales, volume I}

A 100 page booklet with amazing stories of adventures and discoveries from GSA members is available. A copy of GSA GeoTales, volume 1, will be sent to you once you complete the coupon below, and include a minimum $\$ \mathbf{5 0}$ contribution to the GSA Foundation. Please send your check and completed coupon to the Foundation office, and the booklet will be mailed to you immediately.

If you have a tale or two you would like to share for volume 2, please send it via e-mail to drussell@geosociety.org. We are hoping to finalize volume 2 by February 2005 .

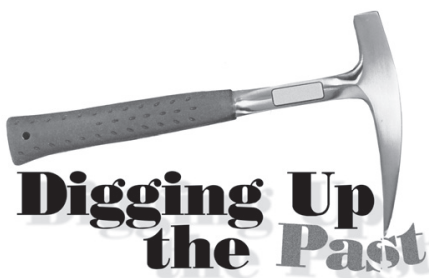

Most memorable early geologic experience:

To illustrate the differences between rational (cause and effect) and empirical deductions in his classes, $\mathrm{J}$. Hoover Mackin used to point out that if you put one foot into a bed of red-hot coals and other foot on a block of ice, the average temperature should be comfortable.

—Donald J. Easterbrook

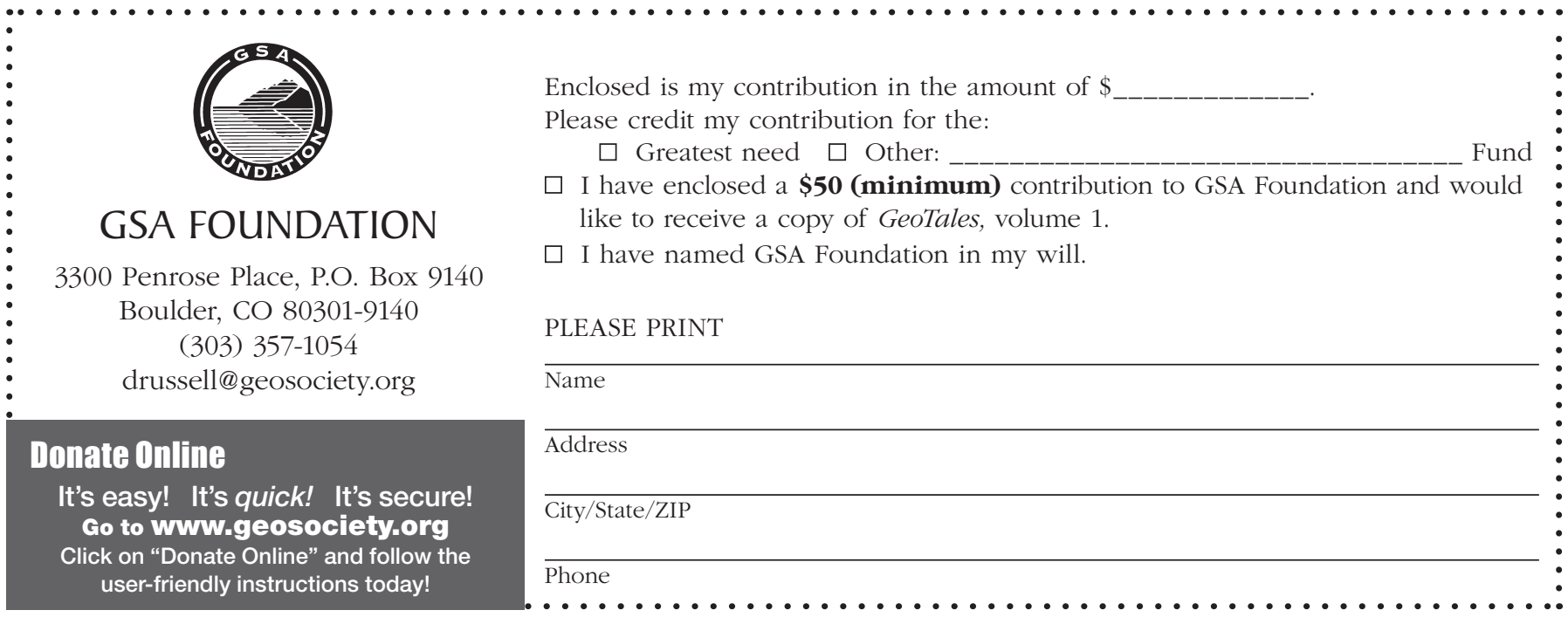




\section{DEEP}

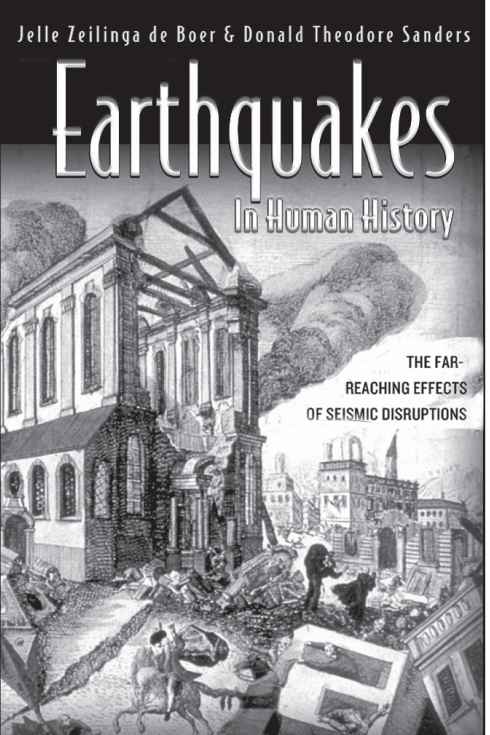

"Earthquakes in Human History moves through the centuries and across the continents to show how earthquakes have shaped different societies. With a cast of characters that includes God, Cleopatra, Voltaire, Mark Twain, and the Sandinistas, it is an engaging and at times thrilling tale" - Charles Walker, University of California, Davis

Cloth \$24.95 ISBN 0-691-05070-8

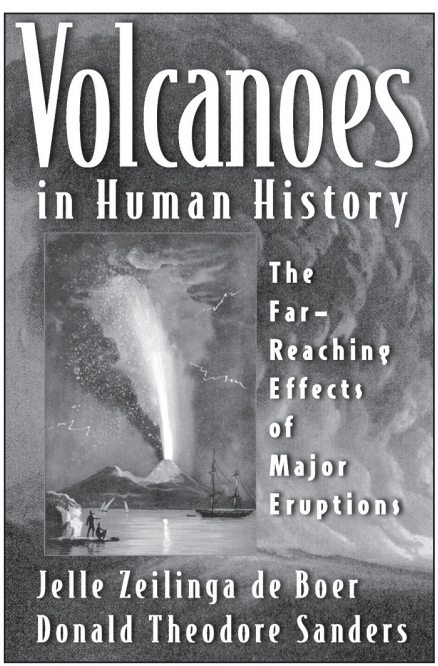

With a foreword by Robert D. Ballard

"Does the world need another book about volcanic eruptions and the havoc they wreak? The answer, for this book, is an emphatic 'yes."

-Sally Newcomb, Isis

New in paper \$18.95 ISBN 0-691-11838-8

\section{PRINCETON} University Press

800-777-4726 U.S. • READ EXCERPTS AT WWW.PUP.PRINCETON.EDU

\section{HISTORY OF GEOLOGY DIVISION INITIATES STUDENT AWARD}

GSA's History of Geology Division is soliciting proposals for a student award for the amount of $\$ 500$ for a paper to be given at the national GSA meeting. It may be:

- A history of geology paper - or-

- A literature review of ideas for technical work

Are you interested in where the ideas that you work with came from? How do you know your research is original? What ideas were prominent in the literature review you did for your thesis or dissertation? Were there ideas that didn't work out? Why? Is your portion of our science "refining the numbers" and extending observations, or are you working on a novel theory? Is there an area of geology whose origins you would like to investigate?

The History of Geology Division would like to hear from you! Mentors are available to help you with this process, or you may work with your own faculty. Contact William Brice, wbrice@pitt.edu, Professor of Geology and Planetary Science, University of Pittsburgh at Johnstown, Schoolhouse Rd., Johnstown, PA 15904, for proposal guidelines and application forms.

Proposals and application are due May 1, 2005, so that content and the official GSA abstract can be refined. The History of Geology Division award committee will make the selection.

\section{GSA Offers Awards in Geomorphology and Micropaleontology}

\begin{abstract}
Two of GSA's most prestigious awards supporting research are made possible by the generosity of the late W. Storrs Cole. Qualified GSA Members and Fellows are urged to apply.
\end{abstract}

The Gladys W. Cole Memorial Research Award

provides support for the investigation of the geomorphology of semiarid and arid terrains in the United States and Mexico. GSA Members and Fellows between the ages of 30 and 65 who have published one or more significant papers on geomorphology are eligible for the award. While the funds may not be used for work that is already finished, recipients of previous awards may reapply if they need additional support

to complete their work. The 2005 award is for $\$ 7,600$.

The W. Storrs Cole Memorial Research Award supports research in invertebrate micropaleontology. This award carries a stipend of $\$ 7,000$ in 2005 and will go to a GSA

Member or Fellow between the ages of 30 and 65 who has published one or more significant papers on micropaleontology.

For 2005 application forms, visit www.geosociety.org/grants/postdoc.htm. For more information, contact

Diane Lorenz, Grants, Awards, and Recognition, GSA, P.O. Box 9140, Boulder, CO 80301-9140, awards@geosociety.org.

Applications must be mailed and must be postmarked on or before February 1, 2005. Applications sent by facsimile or e-mail will not be accepted. The Committee on Research Grants will report its actions to each applicant in April 2005.

THE GLADYS W. AND W. STORRS COLE AWARD FUNDS ARE MANAGED BY THE GSA FOUNDATION. 


\section{GEOLOGICAL SOCIETY OF AMERICA 2004 Published Books}

\section{SPECIAL PAPERS}

Orogenic Curvature: Integrating Paleomagnetic and Stuctural Analyses edited by Aviva J. Sussman and Arlo B. Weil, 2004

SPE383, 272 p., plus index, CD-ROM, ISBN 0-8137-2383-3

$\$ 80.00$, member price $\$ 64.00$

Cenozoic Climatic and Environmental Changes in Russia

edited by A.A. Velichko and V.P. Nechaev (editors of the English-language edition are H.E. Wright Jr., A.A. Velichko, T.A. Blyakharchuk, and Olga Borisova), 2004 SPE382, ISBN 0-8137-2382-5

(In press)

Hydraulic Tests of Miocene Volcanic Rocks at Yucca Mountain and Pahute Mesa and Implications for Groundwater Flow in the Southwest Nevada Volcanic Field, Nevada and California by Arthur L. Geldon, 2004

SPE381, 104 p., ISBN 0-8137-2381-7

$\$ 50.00$, member price $\$ 40.00$

Gneiss Domes in Orogeny

edited by Donna L. Whitney, Christian Teyssier, and Christine S. Siddoway, 2004

SPE380, 378 p., plus index, CD-ROM, ISBN 0-8137-2380-9

$\$ 85.00$, member price $\$ 68.00$

Sulfur Biogeochemistry-Past and Present

edited by Jan P. Amend, Katrina J. Edwards, and Timothy W. Lyons, 2004

SPE379, 205 p., ISBN 0-8137-2379-5

$\$ 75.00$, member price $\$ 60.00$

Detrital Thermochronology-Provenance Analysis, Exhumation, and Landscape Evolution of Mountain Belts

edited by Matthias Bernet and Cormelia Spiegel, 2004

SPE378, 126 p., ISBN 0-8137-2378-7

$\$ 55.00$, member price $\$ 44.00$

Precambrian Geology of the Tobacco Root Mountains, Montana edited by John B. Brady, H. Robert Burger, John T. Cheney, and Tekla A. Harms, 2004 SPE377, 256 p., plate, ISBN 0-8137-2377-9

$\$ 100.00$, member price $\$ 80.00$

Posture, Locomotion, and Paleoecology of Pterosaurs

by Sankar Chatteriee and R.J.Templin, 2004

SPE376, 64 p., ISBN 0-8137-2376-0

$\$ 50.00$, member price $\$ 40.00$

Natural Hazards in El Salvador

edited by William I. Rose, Julian J. Bommer, Dina L. López, Michael J. Carr, and Jon J. Major, 2004

SPE375, 480 p., plus index, ISBN 0-8137-2375-2

$\$ 100.00$, member price $\$ 80.00$

\section{MEMOIR}

Proterozoic Tectonic Evolution of the Grenville Orogen in North America edited by Richard P. Tollo, Lovise Corriveau, James Mclelland, and Mervin J. Bartholomew, 2004

MWR197, 798 p., plus index, ISBN 0-8137-1197-5

$\$ 195.00$, member price $\$ 156.00$

\section{GSA FIELD GUIDES}

Field Trips in the Southern Rocky Mountains, USA

edited by Eric P. Nelson and Eric A. Erslev, 2004

FLD005, 242 p., ISBN 0-8137-0005-1

$\$ 45.00$, member price $\$ 36.00$

Western Cordillera and Adjacent Areas

edited by Terry W. Swanson, 2003

FLD004, 284 p., ISBN 0813700043

$\$ 45.00$, (sorry, no additional discounts)
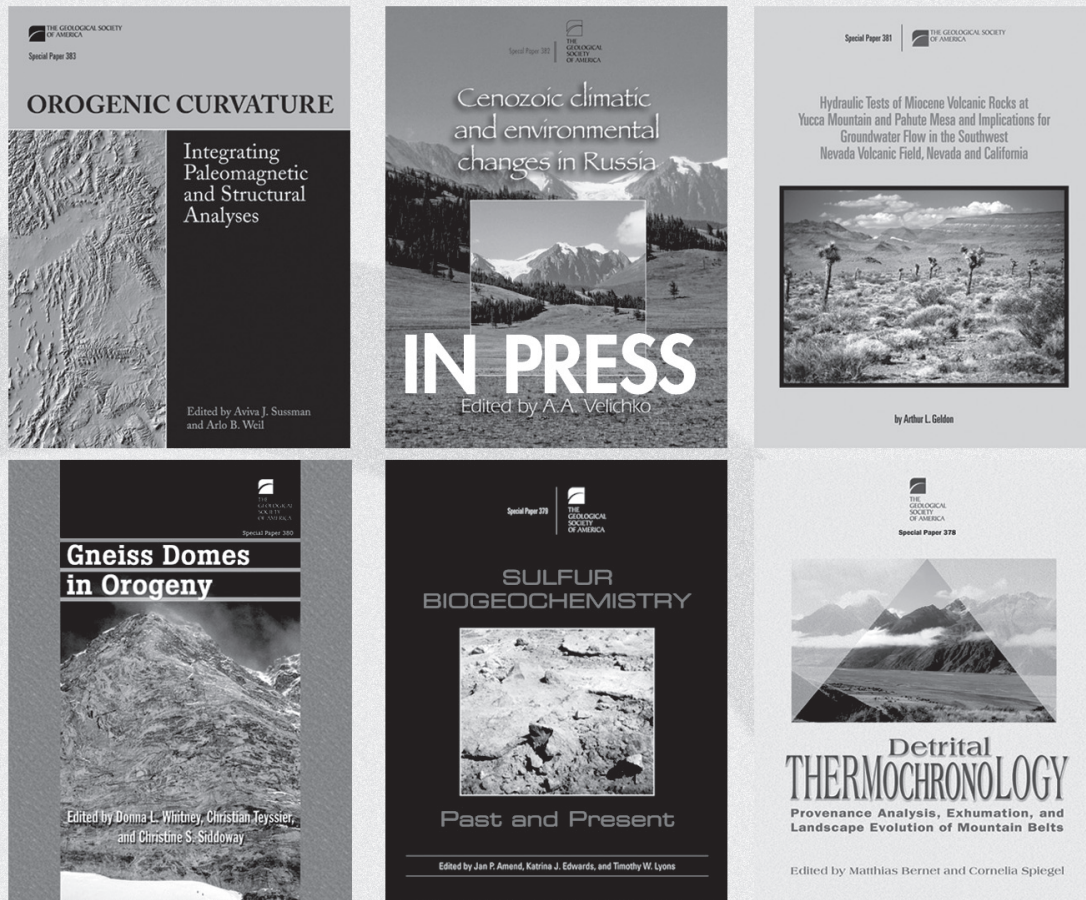

Detrital
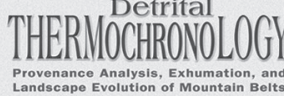

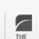

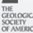
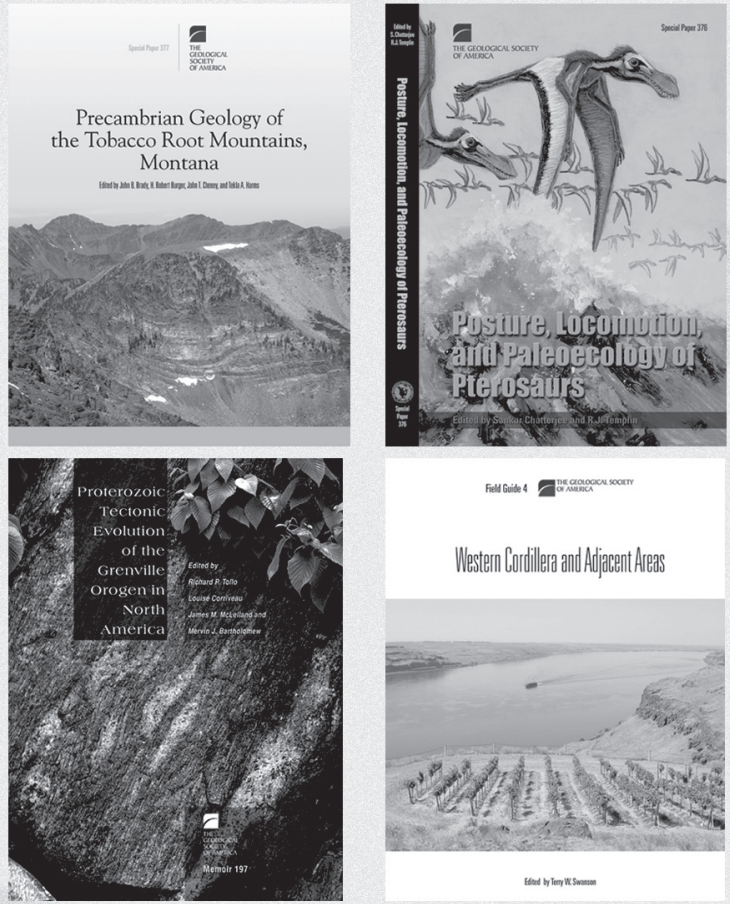

Western Coridillera and Adididernt Aregas
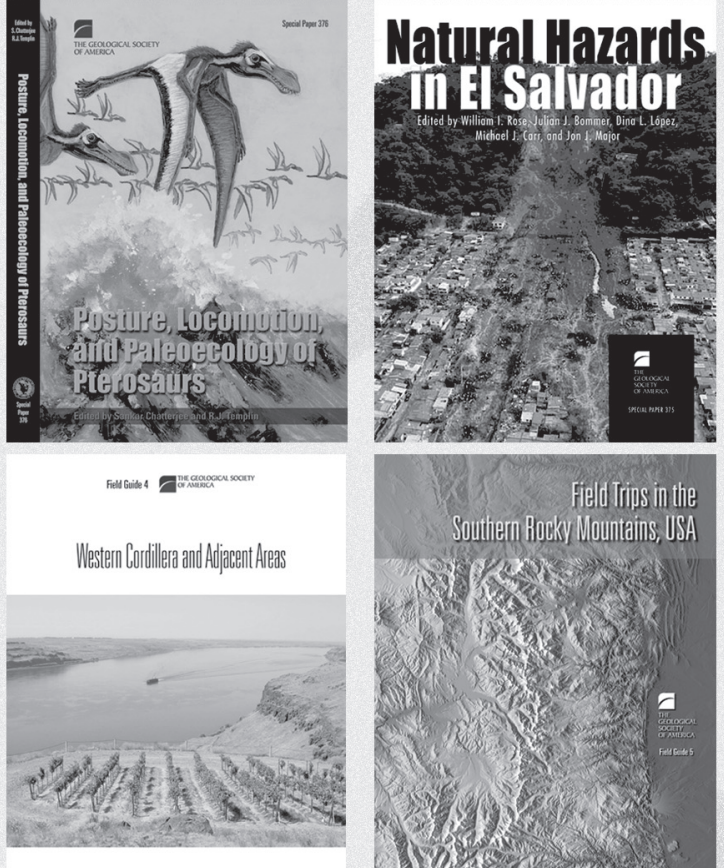

Field Irins in the

Soutitierm Houky Mlountiains, USH

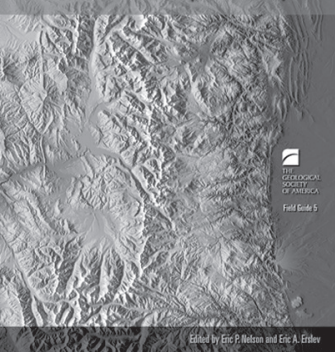

THE GEOLOGICAL SOCIETY OF AMERICA

GSA Sales and Service P.O. Box 9140, Boulder, C0 80301-9140

www.geosociety.org - (303) 357-1000, option 3 - toll freel-888-443-4472 - fax 303-357-1071 


\section{MEETINGS CALENDAR}

\begin{tabular}{ll}
$\mathbf{2 0 0 5}$ & \\
March 29-April 1 & $\begin{array}{l}\text { Partnering for the Global Hydrogen Future: Annual Hydrogen Conference \& Exposi- } \\
\text { tion, Washington, D.C. Information: National Hydrogen Association, (202) 223-5547, } \\
\text { info@hydrogenassociation.org, www.hydrogenconference.org. }\end{array}$ \\
\hline June 20-24 & $\begin{array}{l}\text { Uranium 2005: International Symposium on Uranium Production and Raw Materials for the } \\
\text { Nuclear Fuel Cycle-Uranium Supply and Demand, Uranium Geology, Uranium Production, } \\
\text { Uranium Mining and Milling, Waste Management, and Environment and Safety; Vienna, Austria. } \\
\text { Information: Karen Wenrich, Scientific Secretary, International Atomic Energy Agency, NEFW, } \\
+43-1-26000, \text { fax +43-1-26007, K.J.Wenrich@iaea.org, Uranium2005@iaea.org. }\end{array}$ \\
\hline $\mathbf{2 0 0 6}$ & $\begin{array}{l}\text { Oil \& Gas Habitats of Russia and Surrounding Regions, London. Information: www.geolsoc.org. } \\
\text { uk, Lucy Kimber, lucy.kimber@geolsoc.org.uk. }\end{array}$ \\
\hline Apruary 8-9 & $\begin{array}{l}\text { America, Earthquake Engineering Research Institute, and the California Governor's Office of } \\
\text { Emergency Services. Information: www.1906eqconf.org/; field trip information: cprentice@usgs. } \\
\text { gov. Field trip proposals deadline: March 1, 2005. }\end{array}$
\end{tabular}

Visit www.geosociety.org/calendar/ for a complete list of upcoming geoscience meetings.

\section{Call for Nominations: 2005} Laurence L. Sloss Award

Each year the Sedimentary Geology Division of GSA offers the L.L. Sloss award for lifetime contributions to the field of sedimentary geology and service to GSA. This award is a significant honor for the top sedimentary geologists of our time. Previous awardees include Bill Dickinson, Bob Dott, George Kline, Pete Palmer, Bob Weimer, and James Lee Wilson. To make a nomination, please include a cover letter describing the nominee's accomplishments in sedimentary geology and contributions to GSA and a curriculum vitae for the nominee. The award will be presented at the 2005 GSA Annual Meeting in Salt Lake City. Nominations remain active for three years. Please send your nominations electronically by Feb. 20, 2005, to Paul Link, secretary, Sedimentary Geology Division, linkpaul@isu.edu.

\section{iScienceProject Launches K-12 Energy Contest}

Sponsored by iScienceProject, the HOBO Energy Challenge promotes energy awareness within schools with a fun, hands-on science learning tool, $\mathrm{HOBO}^{\circledR}$ data loggers (portable electronic recording devices that monitor light usage, room temperature, and relative humidity to find examples of energy waste). Participating classrooms will receive a free HOBO Loaner Package that includes a data logger, software, and energy-saving contest activities. Information: www. iscienceproject.com/energy_challenge/energy_challenge.html. Deadline for contest entries: April 30, 2005.

\section{CALL FOR SCHOLARSHIP APPLICATIONS}

Each year, the Dan David Prize awards 10 scholarships of US $\$ 15,000$ each to outstanding doctoral students and postdoctoral researchers from universities all over the world. In addition, 10 scholarships of US $\$ 15,000$ each are awarded to outstanding doctoral students from Tel Aviv University. For information on applying and on the fields selected for 2005 , visit www.dandavidprize.org. Application deadline: March 30, 2005.

\section{AWG Announces New Officers}

The Association for Women Geoscientists has named the following people to its 2004-2005 Executive Committee: president-GSA member Allyson Anderson, ExxonMobil Exploration Company; president elect-GSA member Laurie E. Scheuing, Quantitative Environmental Analysis LLC; past president-GSA Fellow Helen Delano, Pennsylvania Geological Survey; secretary-GSA member Tamie J. Jovanelly, Ph.D. candidate at Kent State University; treasurer-GSA member Kata McCarville, Institute of Atmospheric Sciences, South Dakota School of Mines and Technology; editor-Marguerite Toscano, Smithsonian Department of Paleobiology; assistant editor-Lorraine Manz, North Dakota Geological Survey; GAEA advertising editor-GSA member Jane H. Gill, environmental geologist, North Carolina; publicistGSA member Pranoti M. Asher, Georgia Southern University; and business manager-Carol Dicks. 


\section{AGI Announces New President and Officers}

The American Geological Institute has named its new president, GSA Member Stephen M. Testa, and new AGI officers: president-elect-GSA Fellow Ernest Mancini; secretary-GSA Fellow Robert H. Fakundiny; and member-at-largeG.W. "Skip" Hobbs.

\section{About People}

GSA Senior Fellow Russell G. Slayback has received the American Geophysical Institute's William B. Heroy Jr. Award for exceptional and beneficial long-term service to AGI. Slayback, president and chairman of the board of directors of Leggette, Brashears \& Graham Inc., earned his degree in geology from Rensselaer Polytechnic Institute in Troy, New York.

GSA Fellow Warren D. Allmon has been recognized for his work leading to the greater understanding and public appreciation of the role the geosciences play in society with AGI's Outstanding Contribution to the Public Understanding of Geoscience Award. Allmon is the director of the Paleontological Research Institution and the Museum of the Earth in Ithaca, New York. He earned his A.B. degree at Dartmouth College in 1982 and his Ph.D. from Harvard University in 1988.

\section{In Memoriam}

\section{Allan P. Bennison \\ Grass Valley, California \\ May 1, 2004}

\section{D.L. Blackstone}

Laramie, Wyoming

May 24, 2004

John W. Blagbrough

Albuquerque, New Mexico

July 11, 2004

\section{Reuben G. Bullard}

Independence, Kentucky

July 3, 2004

\section{Arthur E. Burford}

Hudson, Ohio

August 1, 2004

\section{George H. Davis}

Gaithersburg, Maryland

May 24, 2004

William J. Domoracki

Columbia, South Carolina July 25, 2004

Leo A. Herrmann

Ruston, Louisiana

July 16, 2004

Alan D. Hoagland

Murfreesboro, Tennessee

August 1, 2004

\section{John H. Hoke}

Sardinia, Italy

September 18, 2004

\section{W.G.Q. Johnston}

Saskatchewan, Canada

May 14, 2004

Helen Tappan Loeblich

Yorba Linda, California

August 18, 2004

Frederic B. Loomis

Peoria, Arizona

April 23, 2004

\section{John A. Mann}

Yorba Linda, California

September 19, 2004

Barney C. McCasland Jr. Midland, Texas

June 12, 2004

David A. Morris

Oklahoma City, Oklahoma April 14, 2004

Elmer D. Patterson Roswell, New Mexico July 24, 2004

John B. Reid Jr. Amherst, Massachusetts Notified August 3, 2004
Donald H. Richter

Anchorage, Alaska

October 8, 2004

\section{Robert P. Sharp}

Pasadena, California

May 24, 2004

Harold K. Stager

Bodega Bay, California

October 9, 2004

Sherwood D. Tuttle

Fort Thomas, Kentucky

June 27, 2004

\section{Karen M. Weber \\ Blacksburg, Virginia \\ May 26, 2004}

\section{Peter V. Wiese}

Fairhope, Alabama

October 13, 2004

\section{Keith P. Young}

Austin, Texas

August 20, 2004

Please contact the GSA Foundation at (303) 357-1057 or drussell@geosociety.org for information on contributing to the Memorial Fund.

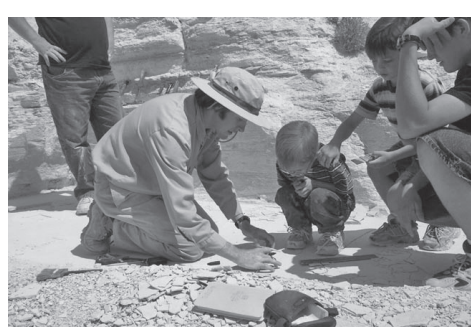

Neil Kelley, GeoCorps 2004, Fossil Butte National Monument

2005 Summer Positions Posted

Spend your summer working on a priority geoscience project in a National Park or National Forest.

\section{GeoCorps $^{\mathrm{TM}}$ America Program}

Through the GeoCorps America Program, GSA offers geoscientists of all levels-university students, professionals, and retirees - a 10 week summer experience working in a National Park or National Forest on a priority land management project to protect America's public lands.

All 2005 summer positions are posted on the Web site listed below. To find out more about the GeoCorps program, positions and locations on National Parks and National Forests, or how to apply, refer to:

http://www.geosociety.org/geocorps

\section{Deadline to apply is Friday, February 11, 2005}

Apply today to be involved in an exciting on-the-ground project on America's public lands this summer! 


\title{
GEOLOGIC PAST
}

\section{Years Ago}

\section{GLACIERS A HOT TOPIC}

H.L. Fairchild's paper, "Ice Erosion Theory a Fallacy," printed in GSA Bulletin

"Probably there is no subject in geology on which the divergence of opinion is so great while at the same time the observational material is so ample as that of glacial erosion" (H.L. Fairchild, p. 14). In his February 1905 GSA Bulletin article, H.L. Fairchild addressed the "extreme differences of opinion and the sudden and radical shifting of views" (p. 15) regarding ice erosion in order to argue against the view that "glaciers possess great erosive power."

In this refutation of ice erosion theory, Fairchild included a brief definition of erosion, presented an extensive discussion on the nature and activity of glaciers around the world, and then focused on ice-sheet erosion in the state of New York, USA. Fairchild was also known as an avid and skilled photogra- pher, and the Bulletin article includes several photographs taken of quarries and building sites throughout New York state.

Herman Leroy Fairchild (1850-1943) was a GSA founding member in 1888 and served as GSA secretary from 1891 to 1906 and GSA president in 1912. Fairchild first presented this controversial paper in two parts at the GSA Philadelphia and St. Louis meetings in January and December 1904, respectively.

50 Years Ago

FRACTURES, CLAY, MAKE GEOLOGY LESS DULL

Ernst Cloos' address to GSA on "Experimental Analysis of Fracture Patterns" printed in GSA Bulletin In his address as retiring president of GSA, published in GSA Bulletin in March 1955, Ernst Cloos stated, "The importance of fractures can hardly be exaggerated. Most likely man could not live if rocks were not fractured" (p. 242). As a prelude to encouraging his colleagues to use experimentation to imitate fracture patterns, Cloos noted, "Geology without fractures would be rather dull, and what would the geologist do if he were without faults when his imagination exceeds his geology?" (p. 242).

In this introduction to fracture pattern experimentation, Cloos drew on work by his brother, Hans Cloos, and outlined four scale models for those scientists who wished to engage in the "good deal of fun" (p. 242) to be had in attempting to imitate and measure fault fracture patterns using wet clay, a trowel, a table, boards, wire cloth, and "a lively imagination" (p. 243).

Ernst Cloos (1898-1974) served as president of GSA in 1954, and first presented this paper at the 1954 GSA Annual Meeting in Los Angeles, California.

\section{COMPREHENGIVEANDG SATE. OF. THE.ART!}

\section{Geologic Map of North America}

\author{
Compiled by John C. Reed Jr., John O. Wheeler, and Brian E. Tucholke
}

The new Geologic Map of North America covers 15\% of Earth's surface and differs from previous maps in several important respects: It is the first such map to depict the geology of the seafloor, the first compiled since the general acceptance of plate-tectonic theory, and the first since radiometric dates for plutonic and volcanic rocks became widely available. It also reflects enormous advances in conventional geologic mapping, advances that have led to a significant increase in the complexity of the map. The new map, printed in 11 colors, distinguishes more than 900 rock units, 110 of which are offshore. It depicts more than seven times the number of on-land units as are shown on its immediate predecessor, as well as many more faults and additional features such as volcanoes, calderas, impact structures, small bodies of unusual igneous rocks, and diapirs.

When displayed at earth science institutions and libraries, this map is sure to impress viewers with the grand design of the continent and may inspire some to pursue the science of geology. The new Geologic Map of North America is also a "thinking map," a source for new interpretations of the geology of North America, insights into the evolution of the continent, new exploration strategies for the discovery of mineral and energy resources, and the development of better ways to assess and mitigate environmental risks and geologic hazards.

3 sheets $\left(74^{\prime \prime} \times 39^{\prime \prime}\right)$, scale $1: 5,000,000,28$ p. text
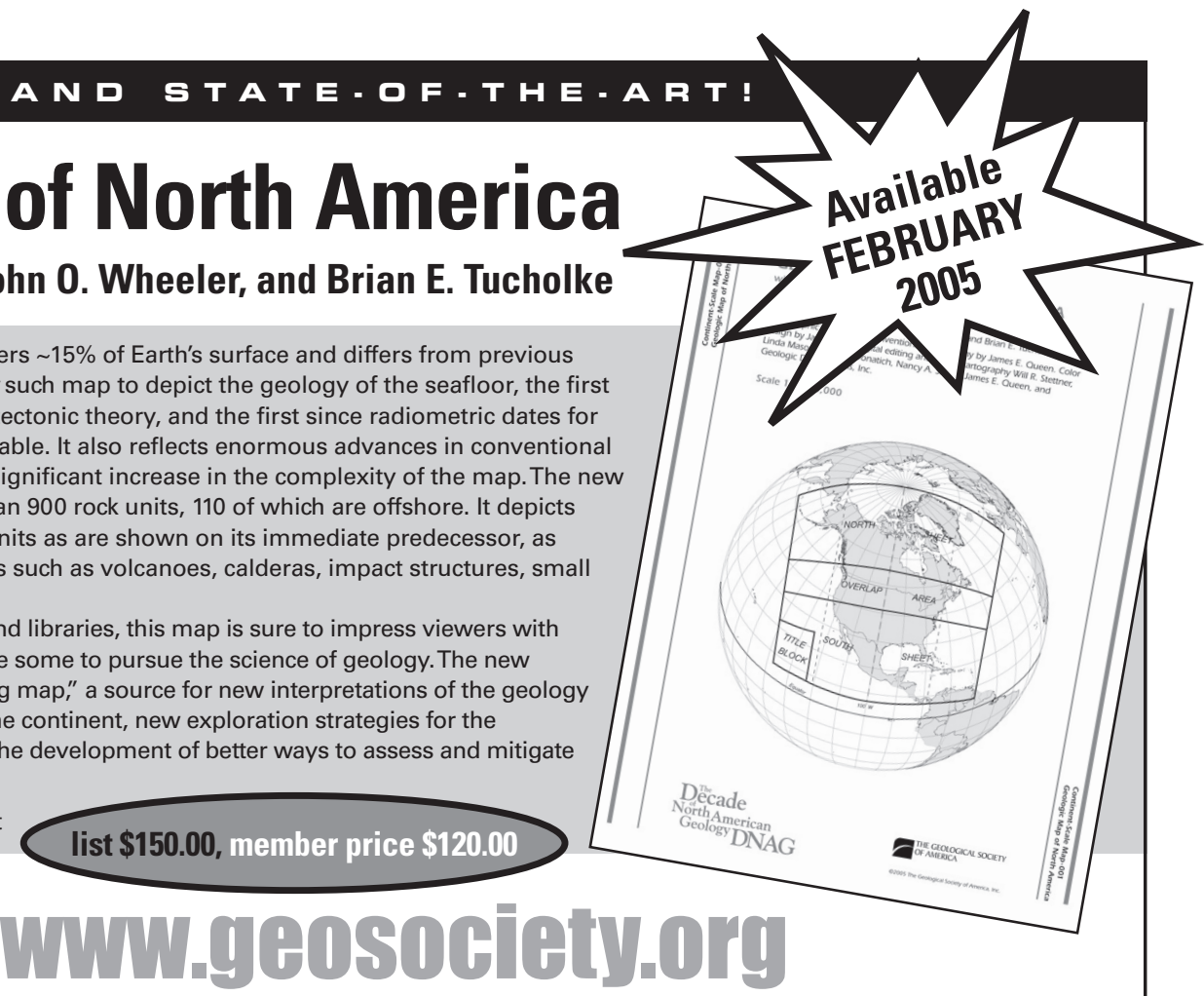

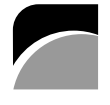

THE GEOLOGICAL SOCIETY OF AMERICA
GSA Sales and Service P.0. Box 9140, Boulder, C0 80301-9140, USA 303-357-1000, option 3 • Toll-free: 1-888-443-4472 • Fax: 303-357-1071 


\section{The Geological Society of America}

GSA Mission, Vision, and Goals Updated for 2005

\section{Mission}

The mission of GSA is to be a leader in advancing the geosciences, enhancing the professional growth of its members, and promoting the geosciences in the service of humankind.

\section{Vision}

- GSA will be a broad, unifying scientific society

- Fostering the human Quest for understanding Earth, planets, and life;

- Catalyzing new scientific ways of thinking about natural systems; and

- Supporting the application of geoscience knowledge and insight to human needs, aspirations, and stewardship of the Earth.

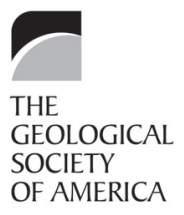

\section{Goals}

1. To increase the Quality and vitality of meetings and conferences.

2. To increase the Quality and vitality of publications.

3. To promote geoscience in the service of society.

4. To attract and sustain a dynamic, dedicated, diverse, and viable membership and to be responsive to this membership.

5. To maintain GSA and the GSAF as financially viable entities.

6. To optimize GSA's governance and organizational structure in fulfillment of GSA's mission.

\section{GSA Beginnings}

The first meeting and the official formation of the Geological Society of America took place in Ithaca, New York, on December 27, 1888. The founders of the GSA were a distinguished group.

James Hall (1811-1898), considered the "elder statesman" of the geological profession at that time, was the first president of GSA. James Dwight Dana (1813-1895), one of the great exploration geologists, was the initial first vice president of the society, while the man believed to have worked the hardest toward the foundation of the GSA, Alexander Winchell (1824-1891), served as initial second vice president. John James Stevenson (1841-1924) was GSA's first secretary, Henry Shaler Williams (1847-1918) was the society's first treasurer, and those elected to serve as members at large were Charles Henry Hitchcock (1836-1919), stratigrapher and paleontologist John Strong Newberry (1822-1892), and Rocky Mountain region geologist John Wesley Powell (1834-1902). The other members of the founding group, many of whom went on to serve as society officers, were Herman LeRoy Fairchild (1850-1943), James Furman Kemp (1859-1926), William John McGee (1853-1912), Henry Bradford Nason (1831-1895), Israel Charles White (1848-1927), John Francis Williams (1862-1891), Samuel Gardner Williams (1827-1900), and Newton Horace Winchell (1839-1914). In 1889, Mary Emilee Holmes (1850-1906) became the first woman GSA Fellow.

This information is taken from GSA Memoir 155, The Geological Society of America-Life History of a Learned Society, by Edwin B. Eckel (1982), and a booklet titled "The Founding of The Geological Society of America," by Arthur Mirskey of GSA's History of Geology Division (1988).

\section{One-stop shopping for all your GSA needs!}

- Register for your upcoming GSA Section meeting and Earth System Processes 2.

- Renew your 2005 membership.

- Subscribe to GSA's outstanding peer-reviewed journals and purchase books, maps, charts, and other publications at member-only rates.

Ensure that you stay connected with GSA by updating your contact information. Recommend GSA membership to your colleagues-applications are online at www.geosociety.org/members/. e-mail: gsaservice@geosociety.org phone: 1.303.357.1000 option 3 or 1.888.443.4472 fax: 303.357 .1071 


\section{EARTHCACHING}

\section{An Adventure Game with an Earthy Twist}

\section{Gary Lewis, GSA Education and Outreach}

$\checkmark$ eocaching is an outdoors phenomenon that is growing rapidly worldwide. Geocaching is an adventure game for Global Positioning System (GPS) users. It involves the creation and placement by players of caches containing a logbook and often other items and the subsequent searching for and locating of these caches by other players. Currently, there are 98,909 caches hidden within the United States and about 500,000 players. Caches are also hidden in over 200 other countries.

The details of each geocache, or the "cache notes," are recorded on a database-driven Web site, www.geocaching. com. This Web site is operated by Groundspeak Inc.

Hunting for a geocache can be an individual pursuit or, more commonly, a group or family affair. Some players use the game as a way to travel to unusual places in the country or to see features that are not marked on tourist maps. Some sites require access by four-wheel drive vehicles and many by hiking.

GSA is involved in setting up some earth science education geocaches, called Earthcaches, in association with the U.S. National Park Service, Forest Service, and other agencies and organizations and in partnership with Groundspeak Inc. and Subaru of America.

As the name implies, Earthcaches are meant for learning about Earth. This includes geological phenomena (fossils, minerals, faults, folds, resources) and geographical features (glacial features, waterfalls, etc.). Already, there are some great GSA Earthcaches in Australia, the United States, and Canada, and some are under development in Germany and Norway.

Earthcaches are a type of "virtual" geocache-that is, they do not involve the creation of physical containers hidden at sites, but rather, Earthcache visitors learn about Earth through the cache notes when they visit the site. Unlike "traditional" caches, the visitors do not leave or remove items from a cache. Some Earthcaches may be established at places where geocachers can log their visits in a book at a visitors' center. All visitors to Earthcaches will be encouraged to log their visits on the Web site.

Earthcaches provide not only location but also a lesson about what the geocacher is seeing. For example, the first Earthcache developed takes the visitor to six places on a headland where they can see evidence of what it was like during the Permian ice age. The cache notes provide the geocacher with an introduction as well as information on each site they visit.

Another Earthcache, in Colorado, takes visitors to a site where Earth's internal forces have injected pegmatite veins of minerals, some as big as a matchbox, into the surrounding country rock. The explanations for how and why this happened are right there in the cache notes in a language understandable for the layperson.

Because Earthcaches are virtual caches, they are a perfect way for many places, both rural and urban, to become cache sites. For example, an Earthcache is currently under development that will take people on a guide of the amazing variety of building stones used in Denver. It will provide the story of each stone type as well as other information. This will be a perfect way for teachers to take inner city kids on a geology field trip using GPS technology.

Earthcaches, because of their educational nature, go through a special approval process in which the language and appropriateness of the cache are tested by the GSA Earthcache team. The team uses a set of guidelines (which you can read at www. earthcache.org) as well as their own earth science experience to ensure that the quality of Earthcaches is maintained. The Earthcache team is also expanding to make sure that caches in languages other than English are not excluded from the project.

So, how do you develop an Earthcache? First, read the guidelines at www.earthcache.org. The most important guideline is that the cache must really teach the visitor something wonderful about our planet. Just a "view" will not make it as an Earthcache. We would suggest that you check out some of the excellent Earthcaches, like "The Rocks that Grew" Earthcache or the WoolShed Creek Earthcache to see how others have written the accompanying notes. Then complete the online submittal form. The Earthcache team will make a decision on the value of the cache, and if it meets the standards, it is submitted to Geocaching.com to undergo the normal geocache approval process. At this stage, around $60 \%$ of submitted Earthcaches have been approved and listed.

If you would like to work on setting up Earthcaches in your area and would like to discuss these with the Earthcache Team, please contact Gary Lewis, glewis@geosociety.org, or Wesley Massey, wmassey@geosociety.org. 


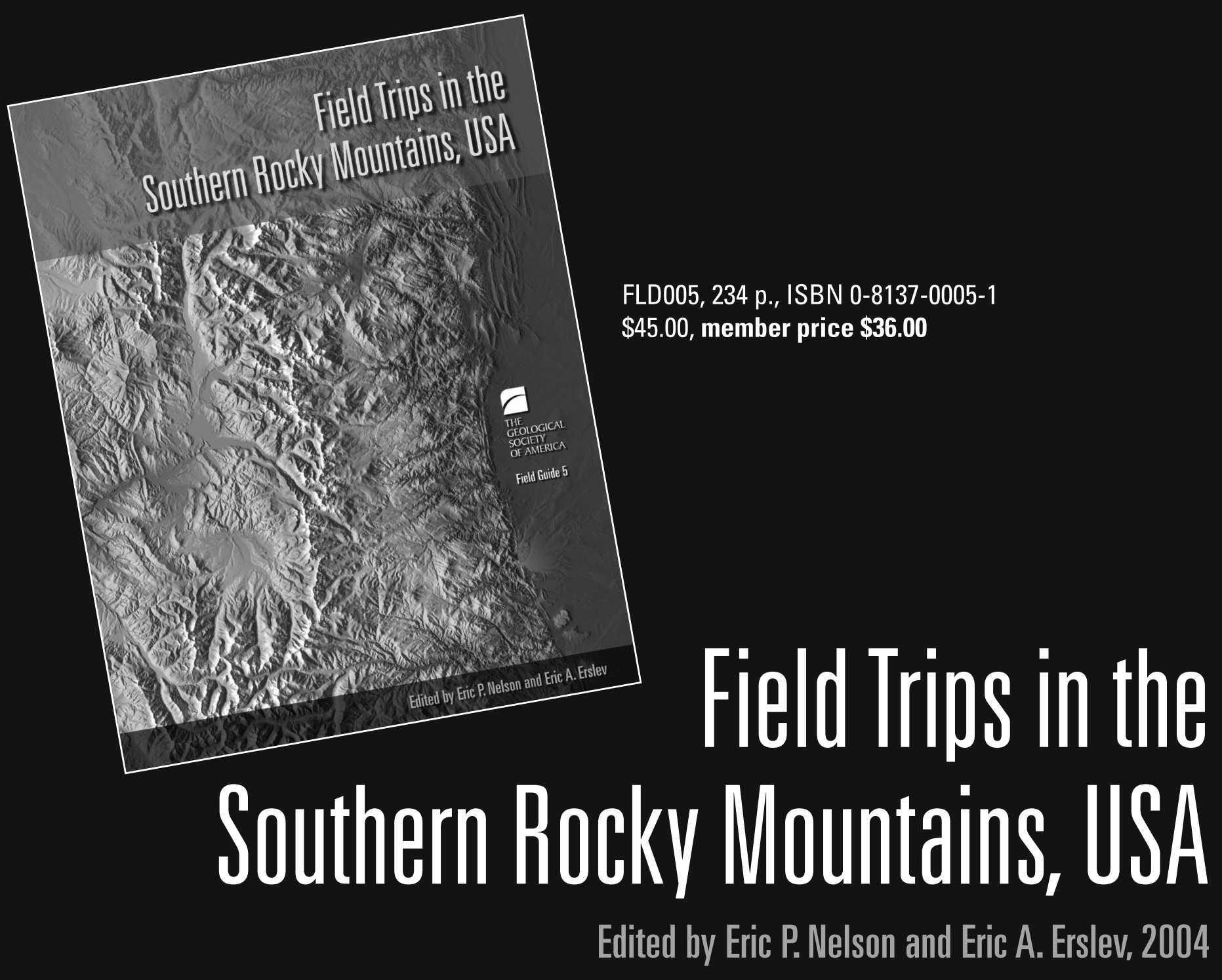

The theme of the 2004 GSA Annual Meeting and Exposition, "Geoscience in a Changing World," covers both new and traditional areas of the earth sciences. The Front Range of the Rocky Mountains and the High Plains preserve an outstanding record of geological processes from Precambrian through Quaternary times, and thus serve as excellent educational exhibits for the meeting. With energy and mineral resources, geological hazards, water issues, geoarchaeological sites, and famous dinosaur fossil sites, the Front Range and adjacent High Plains region provide ample opportunities for field trips focusing on our changing world. The chapters in this field guide all contain technical content as well as a field trip log describing field trip routes and stops. Of the 25 field trips offered at the meeting, 14 are described in the guidebook, covering a wide variety of geoscience disciplines, with chapters on tectonics (Precambrian and Laramide), stratigraphy and paleoenvironments (e.g., early Paleozoic environments, Jurassic eolian environments, the K-T boundary, the famous Oligocene Florissant fossil beds), economic deposits (coal and molybdenum), geological hazards, and geoarchaeology.

GSA Sales and Service P.O. Box 9140, Boulder, C0 80301-9140, USA 303-357-1000, option 3 • Toll-free: 888-443-4472 • Fax: 303-357-1071

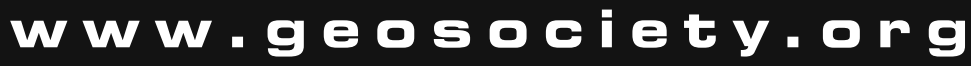
THE GEOLOGICAL SOCIETY OF AMERICA 